\title{
SAVING THE PAST FROM THE FUTURE: Archaeological Curation in the St.Louis District
}
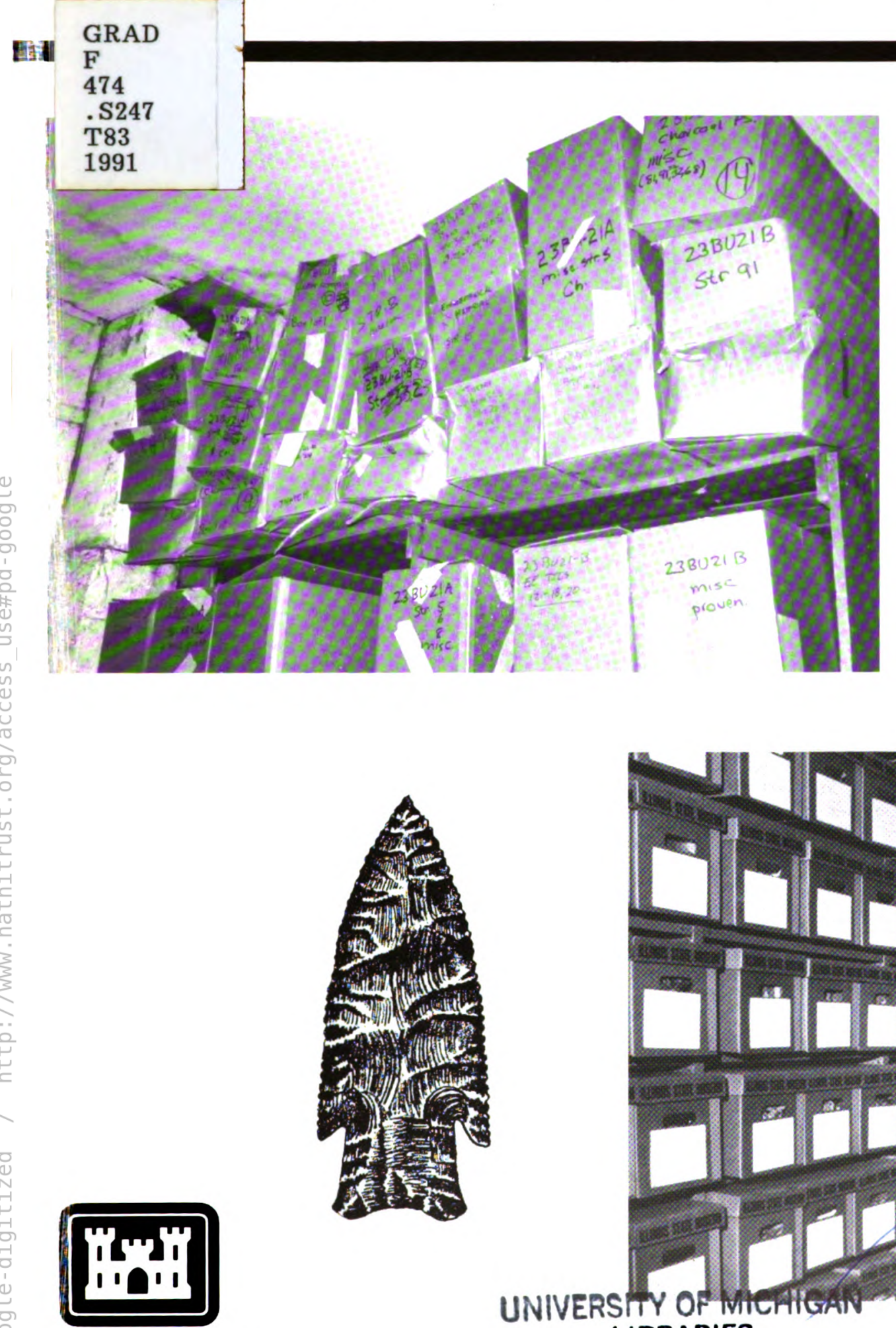

\section{US Army Corps} of Engineers

St. Louis District Revised April 1991

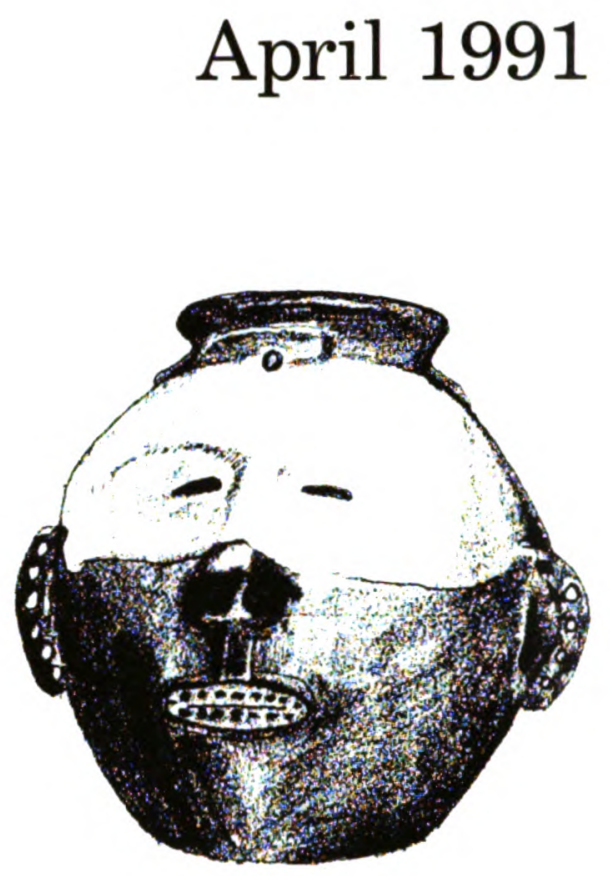

UNIVERSTHY OF MHEAFGAN

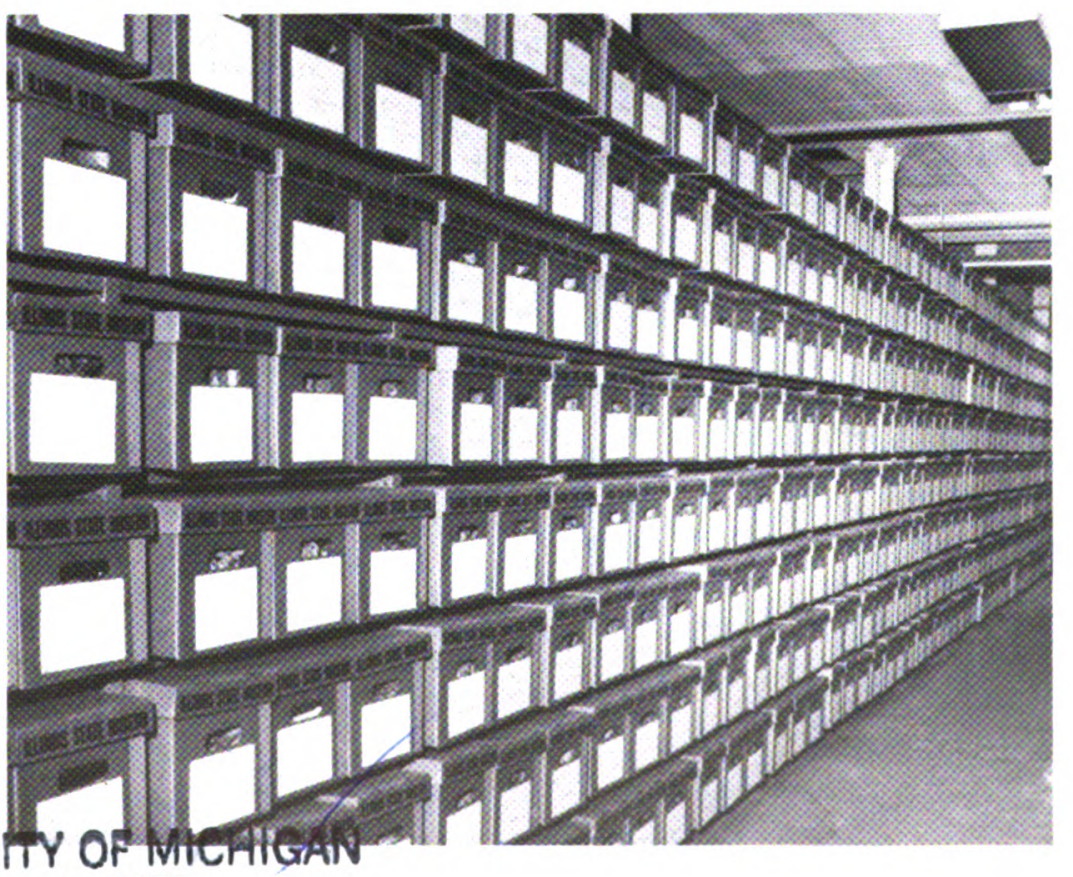
LIBRARIES

MAY 141991 Michael K. Trimble, Ph.D. UNITED STATES OF AMERICA 